University of Nebraska - Lincoln

DigitalCommons@University of Nebraska - Lincoln

Faculty Publications: Department of Entomology

$12-1980$

\title{
Factors Affecting Insecticide-Induced Resurgence of the Brown Planthopper, Nilaparvata lugens on Rice
}

S. Chelliah

E. A. Heinrichs

Follow this and additional works at: https://digitalcommons.unl.edu/entomologyfacpub

Part of the Agriculture Commons, and the Entomology Commons

This Article is brought to you for free and open access by the Entomology, Department of at

DigitalCommons@University of Nebraska - Lincoln. It has been accepted for inclusion in Faculty Publications:

Department of Entomology by an authorized administrator of DigitalCommons@University of Nebraska - Lincoln. 


\title{
Factors Affecting Insecticide-Induced Resurgence of the Brown Planthopper, Nilaparvata lugens ${ }^{1}$ on Rice $^{2}$
}

\author{
S. Chelliah and E. A. Heinrichs
}

Department of Entomology, International Rice Research Institute, Manila, Philippines

\begin{abstract}
Resurgence of the brown planthopper, Nilaparvata lugens (Stål) on rice was induced by applications of decamethrin, methyl parathion, and diazinon. Differential mortality of predators and hoppers did not appear to be the primary factor for resurgence. Hoppers appeared to be attracted to methyl parathion and decamethrin treated plants because of plant growth. Improved plant growth, however, did not compensate for the increased feeding of the insecticide-treated hopper population, and plants treated with resurgence-causing insecticides succumbed to feeding injury earlier than untreated plants.

Population increases were due in part to stimulation of reproduction of the hopper, either by contact action of the insecticides or through increased plant growth. Reduction in the length of the nymphal stage and increased adult longevity resulting in a shortened life cycle and longer oviposition period, respectively, were additional factors contributing to resurgence.
\end{abstract}

\section{Introduction}

The post-treatment resurgence of a target pest or secondary pests after application of chemical insecticides has been documented in a variety of crops (Reynolds 1971, Eveleens et al. 1973, and Shepard et al. 1977). Insecticide-induced pest outbreaks have been attributed mainly to deleterious effects of pesticides on natural enemies, reduction in competitive pest species, and improved nutritive quality and growth of host plants (McClure 1977). There is further evidence that insecticide residues in host plants or insecticides applied at sublethal doses stimulate the reproduction and survival of phytophagous insects 
and mites, leading to pest resurgence (Dittrich et al. 1974, EI-Lakwah and Abdel-Salam 1974, Vrie et al. 1972).

The brown planthopper Nilaparvata lugens (Stål) has recently become one of the most important pests of rice in several Asian countries (Dyck and Thomas 1979). It is a serious threat to the crop because of its direct damage from feeding and because it is a vector of grassy stunt virus. Recently, this species has been reported to transmit 2 additional viruses causing ragged stunt (Ling et al. 1978) and wilted stunt (Chen et al. 1978). In Japan and Taiwan where insecticides are extensively used, $N$. lugens has developed resistance to lindane (Nagata and Mariya 1974) and MIPC and MTMC (Lin et al. 1979), respectively. Resistant rice varieties have succumbed because of the development of biotypes of the hopper which can destroy the resistant variety. In the Philippines, applications of decamethrin, methyl parathion, and diazinon caused N. lugens resurgence while Perthane did not (IRRI 1969, 1971, 1974, 1977). Hopper resurgence after application of parathion, gamma-BHC, carbaryl, or monocrotophos in the Solomon Islands was attributed to the destruction of the mirid predator, Cyrtorhinus lividipennis Reuter according to Stapley et al. (1977). ${ }^{3}$ Cyrtorhinus lividipennis is the most abundant predator of N. lugens on the IRRI farm (Dyck and Orlido 1977). Suenaga (1963) reported C. lividipennis to be the major predator of $N$. lugens eggs in Japan. In the Philippines, N. lugens eggs and nymphs are attacked (Bae and Pathak 1966). At IRRI the mirid bug has been recorded to feed on $4.1 \mathrm{~N}$. lugens eggs and 0.4 nymphs per day (IRRI 1979). However, the causes of resurgence have not been firmly established. These studies were undertaken to investigate the role of certain biological factors as possible causes for brown planthopper resurgence.

\section{Materials and Methods}

The experiments to determine biological parameters of $N$. lugens were carried out in an insectary where the temperature and relative humidity were regulated at $27 \pm 1^{\circ} \mathrm{C}$ and 60 $70 \%$, respectively, with $12 \mathrm{~h}$ illumination/day. Studies of plant growth and tillering were conducted in the greenhouse where temperature, light, and humidity were not controlled. Rice variety Taichung Native 1, which is highly susceptible to the test insect, was used in all studies.

The following insecticides were used in the experiment: Perthane (1, 1-dichloro 2, 2-di(4-ethylphenyl ethane) $(0.04 \%)$, methyl parathion (0,0 dimethyl 0-4-nitrophenyl phosphorothioate) $(0.04 \%)$, diazinon (0,0-diethyl 0-isopropyl-6-methyl pyrimidin-4-yl-phosphorothioate $(0.04 \%)$, and decamethrin (NRDC 161-Decis) ( $\mathcal{L}$-cyano-3-phenoxybenzyl $d$ cis 2 , 2 dimethyl (2.2 dibromovinyl) cyclopropane carboxylate) $(0.002 \%)$. The quantity of spray fluid sprayed with an atomizer was calculated as based on the volume applied in the field (500 1/ha). Insecticides were applied at 20, 30, and 40 days after planting, unless otherwise mentioned. The insects were placed on test plants at various intervals after the last spraying, as necessitated in individual experiments.

The toxicity of insecticides to $N$. lugens and the predator $C$. lividipennis was assessed as follows. The plants received one spray application and at $24 \mathrm{~h}$ after spraying, 10 insects

were released per plant. Mortality was recorded the following day. Observations were 
continued up to 10 days after spraying, and the corrected mortality was determined using Abbott's ( 1925) formula.

To determine if hoppers were attracted to the odor of the insecticides, the plants after 3 sprayings were arranged in a circle at a radius of $30 \mathrm{~cm}$ within $45 \times 45 \times 45 \mathrm{~cm}$ wooden cages. The cage top and front wall were covered with glass, and side and back walls made of fine mesh wire screen. Twenty four h after the last spray application, 50 macropterous, field-collected $N$. lugens females, which had been starved for $2 \mathrm{~h}$ were released in a petri dish placed in the center of the cage. The numbers of hoppers alighting on plants in each treatment was recorded daily for 9 days. After each observation, the position of the potted plants was randomized, the plants were shaken to dislodge the hoppers, and the dead hoppers were replaced.

To determine the influence of insecticide-induced plant growth on orientation of the hoppers, plants were taken 15 days after the third spraying and were confined in $100 \times 75$ $\times 75 \mathrm{~cm}$ cages covered with fine mesh nylon screen. Hoppers were introduced into the cage through a slit in the mylar film with the aid of an aspirator. The numbers of hoppers on the different treatments were recorded daily for six days.

To study the growth response of rice plants to foliar sprays of insecticides, two 15-dayold seedlings were planted/pot and sprayed with insecticides at 20,30, and 40 days after planting. The number of tillers, leaves, and plant height were recorded in individual treatments 15 days after the last spraying.

The relative amount of feeding by $N$. lugens on rice plants was assessed using two methods; measurement of the radioactivity in insect and honeydew excreted by the hoppers feeding on ${ }^{32} \mathrm{P}$ labeled plants (Lippold et al. 1978) and by measuring the amount of honeydew excreted on filter paper.

In the ${ }^{32} \mathrm{P}$ study, potted, 35-days-old rice plants were sprayed with Perthane $(0.04 \%)$, methyl parathion $(0.04 \%)$, diazinon $(0.04 \%)$, and decamethrin $(0.02 \%)$ using a revolving table and an atomizer. The quantity of spray fluid used was based on a field spray volume of 500 l/ha. The control plants were sprayed with water, and treatments were replicated 6 times.

Fifteen days after spraying, soil was washed from the roots, and each plant was placed in a 150-ml Erlenmeyer flask with roots immersed in $100 \mathrm{ml}$ of distilled water containing $1.0 \mu \mathrm{c} / \mathrm{ml}{ }^{32} \mathrm{P}-\mathrm{H}_{3} \mathrm{P}_{04}$. Each stem was inserted through a central hole in an inverted plastic petri dish $(10 \mathrm{~cm} \mathrm{dia})$. A Whatman No. 1 filter paper $(7.0 \mathrm{~cm})$ was fixed around the stem over the petri dish. The stem was then inserted through an inverted, transparent plastic cup cage, with provisions for good ventilation and the cage fixed tightly over the filter paper on which the honeydew was collected. Five nymphs per replicate were starved for $2 \mathrm{~h}$. At $24 \mathrm{~h}$ after the plants were placed in the ${ }^{32} \mathrm{P}$ solution, the prestarved insects were released into the cage fixed around the plant stem. After confining the insects for $24 \mathrm{~h}$ on labeled plants, they were removed, anaesthetized, and radio activity of the insects and the honeydew on the filter paper measured using a GM counter (Nuclear-Chicago, Model No. 8400). The counts were recorded for $5 \mathrm{sec} / \mathrm{sample}$, a sample consisting of 5 insects and one filter paper. The total sap ingested by the hoppers in $24 \mathrm{~h}$ was indirectly assessed by summing the radio activity in the hoppers and filter paper. 
With the filter paper technique (IRRI 1969) thirty-day-old plants grown individually in pots were sprayed with the test insecticides. Ten days later, when residual activity was too low to cause hopper mortality, a feeding chamber was placed around each plant as described in the earlier test. The honeydew excreted by the insects in $24 \mathrm{~h}$ which was absorbed by the filter paper was treated with $0.001 \%$ ninhydrin in acetone and oven dried at $100^{\circ} \mathrm{C}$ for $5 \mathrm{~min}$. The purple ninhydrin positive spots in each treatment were measured in $\mathrm{cm}^{2}$ and the area termed as a feeding index.

The damage caused by the hoppers on plants sprayed with insecticides was assessed by the time taken for the insects to cause complete hopper-burning of the test plants. Fifteen days after the third spraying 20 fourth instar nymphs were released per replication on the 55-day-old plants, and the dead insects were replaced by insects of similar age up to 8 days after initial release.

The reproductive rate of the hoppers on insecticide-sprayed plants was recorded as follows. Two gravid females were released in each of the replicates at 15 days after the third spraying and were confined for 7 days on plants within mylar film cages. The reproductive rate was assessed by counting the emerging nymphs.

Observations on the nymphal duration were made by confining newly hatched nymphs at 15 days after the third spraying on the basal stem portion of rice plants using cylindrical plastic cages with nylon screen at the top and bottom. Daily checks were made to determine if molting had occurred. Only methyl parathion and decamethrin were used in this study.

The sex ratio was determined for adults which had been reared during their nymphal development on plants of the different treatments. Longevity of adult females was determined placing newly transformed hoppers on plants 15 days after spraying and daily recording the mortality of individual insects.

\section{Results}

\section{Toxicity of insecticides to $\mathrm{N}$. lugens and C. lividipennis}

The toxicity of four insecticides to N. lugens and C. lividipennis, an important predator of the hopper, is presented in Figure 1. Among the insecticides tested, Perthane had the most persistence against hoppers, with about $30 \%$ mortality on the eighth day. With the other three insecticides the corrected mortality was less than $14 \%$, even by the fifth day after spraying. 


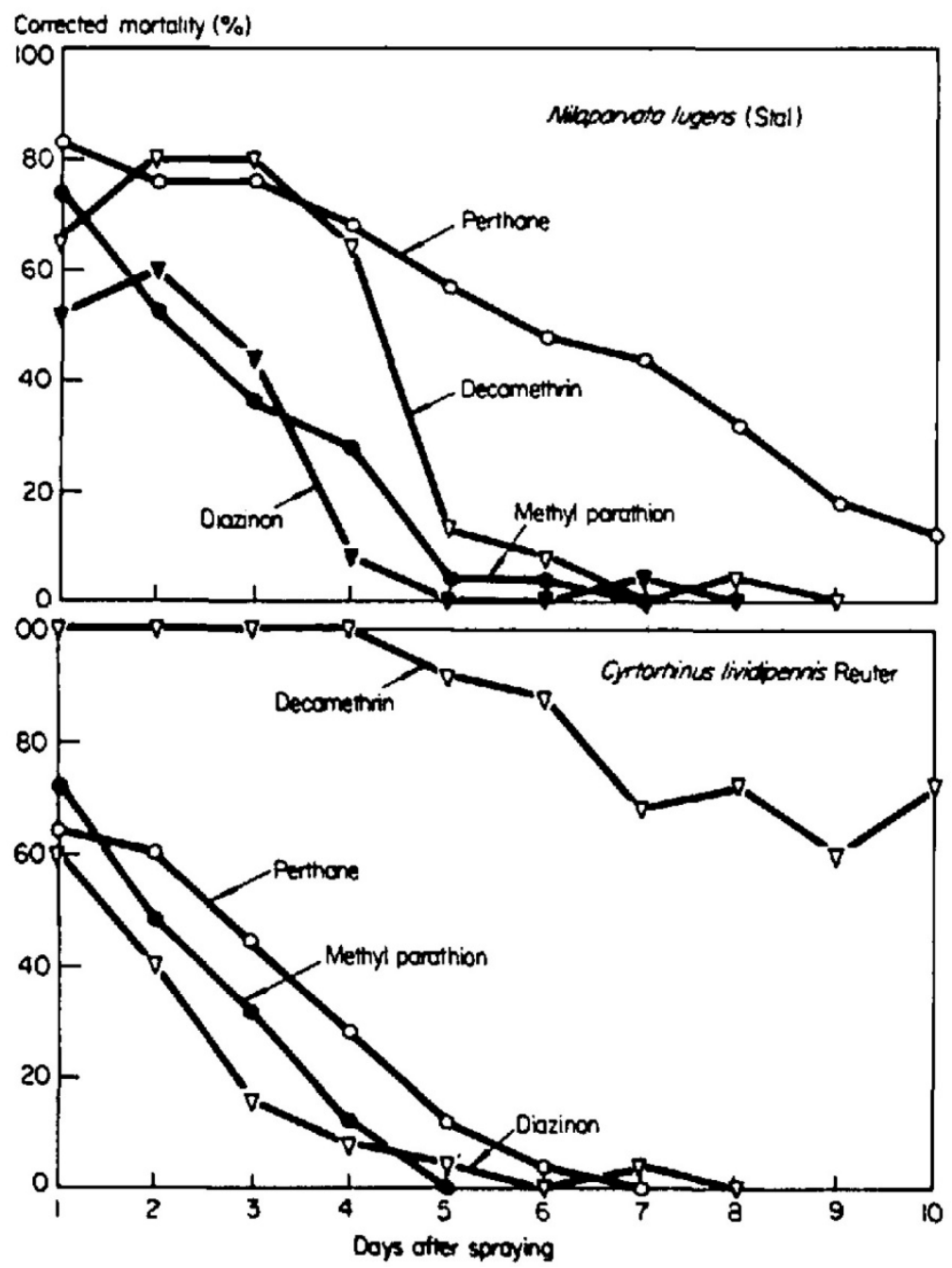

Figure 1. Residual toxicity of insecticides sprayed on rice to N. lugens and a predator, C. lividipennis.

The mortality rate of $C$. lividipennis dropped to below $40 \%$ on the third day after spraying with diazinon and methyl parathion, two insecticides causing resurgence. Results with Perthane, an insecticide which does not cause resurgence, were similar to those for methyl parathion and diazinon. However, on decamethrin treated plants, mortality was as high as $72 \%$, even on the tenth day after spraying. Thus, there is a distinct difference in predator mortality even among the resurgence-causing insecticides.

\section{Effect of insecticide spray on the orientational response of hoppers}

The odor from the insecticide residues had no influence on the orientation of the hoppers (Table 1). However, improved plant growth caused by insecticides did influence the orientational response of the hoppers. Plants sprayed with methyl parathion and decamethrin 
produced more tillers and leaves. This increased growth caused the plants to be more attractive to the hoppers (Table 1). Diazinon, an insecticide causing resurgence, and Perthane, a nonresurgence-inducing insecticide, did not, however, differ from the control in improving the plant growth and attraction of adult hoppers. Further, the variation in plant height among the treatments did not appear to be a factor affecting the orientation of the hoppers.

Table 1. Effect of spray of insecticides on plant growth and on the orientational response of brown plant hopper, Nilaparvata lugens (Stål) as influenced by odor stimulus and plant growth

\begin{tabular}{|c|c|c|c|c|c|}
\hline \multirow[b]{2}{*}{ Treatment } & \multicolumn{2}{|c|}{ Orientational response as influenced by ${ }^{1}$} & \multicolumn{3}{|c|}{ Changes in plant growth } \\
\hline & \multicolumn{2}{|c|}{ (\% adults alighted $)$} & $\begin{array}{l}\text { Tiller } \\
\text { (no.) }\end{array}$ & $\begin{array}{c}\text { Leaves } \\
\text { (no.) }\end{array}$ & $\begin{array}{c}\text { Height } \\
\text { (no.) }\end{array}$ \\
\hline Methyl parathion & $24.3 \mathrm{a}$ & $31.5 a$ & $9.8 \mathrm{a}$ & $32.4 a$ & $75.3 a$ \\
\hline Decamethrin & $27.4 \mathrm{a}$ & $28.6 b$ & $7.6 \mathrm{~b}$ & $27.4 \mathrm{ab}$ & $75.4 \mathrm{a}$ \\
\hline Diazinon & $25.9 \mathrm{a}$ & $23.2 \mathrm{c}$ & $6.8 \mathrm{~b}$ & $23.5 b$ & $71.6 \mathrm{ab}$ \\
\hline Perthane & $27.2 \mathrm{a}$ & $23.4 \mathrm{c}$ & $7.2 b$ & $23.5 b$ & $69.6 b$ \\
\hline Control & $26.0 \mathrm{a}$ & $24.3 \mathrm{c}$ & $7.2 \mathrm{~b}$ & $23.5 b$ & $74.7 \mathrm{a}$ \\
\hline
\end{tabular}

1. Transformed (Arcsin) values. In a column, all means followed by a common letter are not significantly different at 0.05 level by Duncan's multiple range test.

\section{Feeding rate and damage}

In the first test, feeding activity as indicated by radioactivity counts was highest in those treatments where resurgence-inducing insecticides were applied. On decamethrin-, methyl parathion-, and diazinon-treated plants, the feeding rate was higher than the control by 61,43 , and $33 \%$, respectively (Table 2). A $24.5 \%$ reduction in the feeding rate was observed in hoppers on Perthane-treated plants.

\begin{tabular}{|c|c|c|}
\hline Treatment & Counts/5 sec/insect ${ }^{1}$ & Increase/decrease over control (\%) \\
\hline Decamethrin & $6308 \mathrm{a}$ & +61 \\
\hline Methyl parathion & $5587 \mathrm{ab}$ & +43 \\
\hline Diazinon & $5185 b$ & +33 \\
\hline Perthane & $2955 d$ & -24 \\
\hline Control & $3912 c$ & - \\
\hline
\end{tabular}

1. Mean ${ }^{32} \mathrm{P}$ activity recorded in 30 th-instar nymphs and in honeydew on 6 filter papers representing 6 replications/treatment. Means followed by a common letter are not significantly different at the 0.05 level by Duncan's multiple range test.

Results of the second feeding test using the filter paper technique were similar. Increased feeding by hoppers was evident on plants sprayed with decamethrin, methyl parathion, and diazinon, as shown by the honeydew measurements (Fig. 2). The amount of honeydew excreted was the lowest from insects feeding on Perthane-treated plants.

Differences were observed in the damage caused by the hoppers on plants sprayed with different insecticides (Fig. 2). With the same population of hoppers, hopperburn appeared 
sooner on plants treated with resurgence-causing insecticides. Diazinon-sprayed plants were hopperburned in 8 days, while decamethrin and methyl parathion-treated plants were hopperburned in 10 days. Because of the low amount of feeding, plants sprayed with Perthane were the last to be completely damaged.

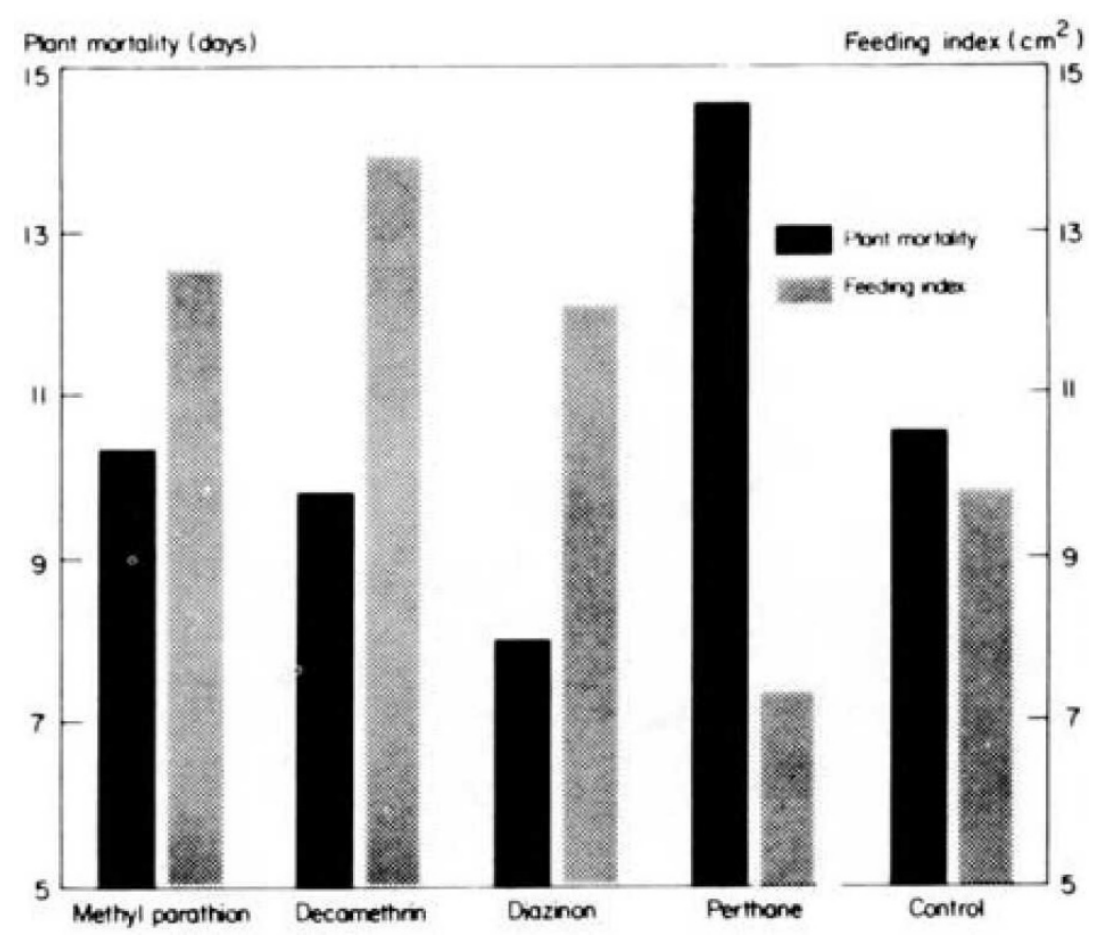

Figure 2. Effect of foliar spray of insecticides on feeding rate and damage by $N$. lugens. The feeding index is based on area of ninhydrin positive spots produced on filter paper by 5 fifth instar $N$. lugens nymphs feeding for $24 \mathrm{~h}$. Plant mortality is the result of feeding damage caused by 20 nymphs placed on each plant at 15 days after the third spray application.

\section{Influence of insecticides on reproductive rate}

There was a significant increase in the reproductive rate of hoppers confined on methyl parathion-, decamethrin-, and diazinon-sprayed plants after the insecticide residues were too low to cause hopper mortality (Table 3). Hoppers confined on decamethrin-sprayed plants produced 1.9 times as many nymphs as hoppers placed on control plants. Hoppers on Perthane-treated plants had significantly fewer nymphs than the control. 
Table 3. Influence of foliar sprayed insecticides on the ovipositional rate, nymphal duration, sex ratio, and adult longevity of $N$. lugens ${ }^{1}$

\begin{tabular}{lcccc}
\hline Treatment & $\begin{array}{c}\text { Reproductive rate } \\
\text { (No. of nymphs } \\
\text { hatched) }\end{array}$ & $\begin{array}{c}\text { Nymphal duration } \\
\text { (Days) }\end{array}$ & $\begin{array}{c}\text { Sex ratio } \\
(8 / \odot)\end{array}$ & $\begin{array}{c}\text { Adult longevity } \\
\text { (Days) }\end{array}$ \\
\hline Methyl parathion & $292 \mathrm{ab}$ & $14.1 \mathrm{ab}$ & $1.26 \mathrm{a}$ & $11.1 \mathrm{ab}$ \\
Decamethrin & $321 \mathrm{a}$ & $13.6 \mathrm{a}$ & $1.46 \mathrm{a}$ & $12.7 \mathrm{a}$ \\
Diazinon & $275 \mathrm{~b}$ & - & $1.44 \mathrm{a}$ & $9.9 \mathrm{~b}$ \\
Perthane & $125 \mathrm{~d}$ & - & $1.40 \mathrm{a}$ & $10.3 \mathrm{~b}$ \\
Control & $166 \mathrm{c}$ & $14.7 \mathrm{~b}$ & $1.00 \mathrm{a}$ & $10.2 \mathrm{~b}$ \\
\hline
\end{tabular}

1. In a column, means followed by a common letter are not significantly different at the 0.05 level by the Duncan's multiple range test.

\section{Effect of insecticides on nymphal duration, sex ratio, and adult longevity}

The duration of individual nymphal stadia of hoppers on plants sprayed with methyl parathion or decamethrin did not differ significantly from that of the control. However, the total nymphal duration was significantly different among treatments. The hoppers completed their nymphal stage 1.1 days earlier on decamethrin-treated plants than on control plants (Table 3). Although there were more females than males in hoppers cultured on insecticide-sprayed plants, differences among treatments were not significant (Table 3).

\section{Discussion}

Resurgence of the brown planthopper in rice after applications of decamethrin and methyl parathion has been previously reported in the Philippines (IRRI 1977). In other crops, methyl parathion was also reported to cause resurgence of Coccus hesperidum (Hart and Ingle 1971), Plathypera scabera, Heliothis spp., Pseudoplusia includens, Anticarsia gemmatalis, and Epilachna varivestis (Shepard et al. 1977). High toxicity of insecticides like methyl parathion to the natural enemies of the brown planthopper was assumed by earlier investigators to be a major cause of hopper resurgence (Dyck and Orlido 1977, Stapley et al. 19773). This conclusion was based mainly on the mortality of C. lividipennis, an important predator of hoppers. The present study on the toxicity of insecticides to this predator did not lead to such a generalized conclusion.

While decamethrin was toxic to the mirid predator for an extended period, toxicity of methyl parathion and diazinon was comparable to Perthane, an insecticide which does not cause hopper resurgence in the field. Further studies on the toxicity of these insecticides to other important natural enemies, particularly the egg parasites and spiders, are needed to determine whether mortality of natural enemies is a primary factor for hopper resurgence.

Field studies have frequently shown that application of insecticides can result in increased growth of crop plants. Since macropterous immigrants are the primary source of inoculum in a rice field, attraction of hoppers to lush growth of plants may be a possible cause of hopper resurgence. Improved plant growth and increased orientation of hoppers to methyl parathion- and decamethrin-treated plants was apparent. The hoppers that alighted on these plants fed more as indicated by the radiotracer and honeydew excretion 
studies. Previous studies have indicated a positive relationship between ingestion and honeydew excretion by N. lugens (Sogawa and Pathak 1970). Among the insecticides tested, the quantity of honeydew excreted was the lowest in hoppers fed on Perthane-treated plants, suggesting Perthane might act as a feeding deterrent to the hoppers. Related to these results, the damage caused by the hoppers was lowest in Perthane-treated plants, as shown by the time required for plant mortality to occur.

Although methyl parathion- and decamethrin-sprayed plants had increased growth, this growth did not compensate for the higher rate of feeding by hoppers. Plant mortality occurred at almost the same time as it did in the control. However, diazinon did not increase plant growth significantly, although it increased the feeding rate of hoppers. As a result, diazinon-treated plants were the first to succumb to damage.

The reproductive rate of the hopper was higher on plants treated with decamethrin, methyl parathion, and diazinon. This increase may have been due to stimulation of hopper reproduction by the insecticide residues or their metabolites, chemical changes in the host plant receiving insecticides, or a combination of these two factors. These results suggest that a combination of increased reproduction and feeding resulted in rice plants treated with decamethrin, methyl parathion, and diazinon being damaged sooner than untreated plants. Reduced nymphal duration and increased adult longevity are additional biological factors which would contribute to resurgence under field conditions.

Further studies will be required to determine if chemical changes in the rice plants cause the changes in the biology of the hoppers. While studying the causes for resurgence of the blue leafhopper, Zygina maculifrons (Motch.), in rice Mani and Jayaraj (1976) reported that low concentrations of calcium and high levels of nitrogen and phosporous in treated plants contributed to resurgence. However, chemical analysis of major and minor nutrients in rice plants protected with insecticides, in relation to brown planthopper resurgence did not reveal any marked changes (Chelliah and Heinrichs ${ }^{4}$ ). Nevertheless, studies on the qualitative and quantitative changes in amino acids, sugars, and possibly other nutrients in plants might provide evidence of the chemical basis of resurgence.

An overall analysis of the biological relationships between the brown planthopper and treated rice plants indicates that insecticides such as decamethrin and methyl parathion produce a highly favorable environment for the hoppers to alight, feed, survive, and reproduce. These factors contribute to resurgence, resulting in severe damage to a protected crop after the toxic effect of the insecticide is diminished.

\section{Notes}

1. Homoptera: Delphacidae

2. Received for publication April 9, 1979.

3. Stapley, J. H., Y. Y. Jackson, and W G. Golden. 1977. Observation in the Solomon Islands on the control of the brown planthopper, Nilaparvata lugens (Stål). In Draft papers of a symposium. The Brown Planthopper: Threat to rice production in Asia. Intl. Rice Res. Institute, Los Baños, Philippines. $14 \mathrm{pp}$. 
4. Chelliah, S., and E. A. Heinrichs. 1978. Resurgence of the brown planthopper Nilaparvata lugens (Stål) following insecticide application. Paper presented at the 9th Annual Conference of the Pest Control Council of the Philippines, Manila. May 3-6, 36 pp.

\section{References Cited}

Abbott, W. S. 1925. A method of computing the effectiveness of an insecticide. J. Econ. Entomol. 18:265-7.

Bae, S. H., and M. D. Pathak. 1966. A mirid bug. Cyrtorhinus lividipennis Reuter, predator of the eggs and nymphs of the brown planthopper. IntI. Rice Comm. Newsl. 15(3):33-6.

Chen, C. C., W. H. Ko, and R. J. Chiu. 1978. Rice wilted stunt and its transmission by the brown planthopper, Nilaparvata lugens (Stal). Plant Prot. Bull. Taiwan 20:376.

Dittrich, V., P. Streibert, and P. A. Bathe. 1974. An old case reopened: mite stimulation by insecticide residues. Environ. Entomol. 3:534-40.

Dyck, V. A., and G. C. Orlido. 1977. Control of brown planthopper (Nilaparvata lugens Stål) by natural enemies and timely application of narrow spectrum insecticides. P. 58-72. In The Rice Brown Planthopper. Food and Fertilizer Technology Center for the Asian and Pacific Region, Taipei, Taiwan. 258 pp.

Dyck, V. A., and B. Thomas. 1979. The brown planthopper problem. P. 3-17. In The Brown Planthopper: Threat to Rice Production in Asia. IntI. Rice Res. Institute, Los Banos, Philippines. 369 pp.

EI-Lakwah, F., and F. A. Abdel-Salam. 1974. The action of some organo-phosphates in sublethal doses on Spodoptera littoralis (Boisd). Anz. Schad. Pflan. Umwelt. 47:28-30.

Eveleens, K. G., R. van den Bosch, and L. E. Ehler. 1973. Secondary outbreak induction of beet armyworm by experimental insecticide applications in cotton in California. Environ. Entomol. 2:497-503.

Hart, W. G., and S. Ingle. 1971. Increases in fecundity of brown soft scale exposed to methyl parathion. J. Econ. Entomol. 64:204-8.

International Rice Research Institute. 1969. Annual Report for 1968. Los Baños, Philippines. 402 p.

1971. IRRI Annual Report for 1970. Los Baños, Philippines. 265 p.

1974. IRRI Annual Report for 1973. Los Baños, Philippines. 266 p.

1977. IRRI Annual Report for 1976. Los Baños, Philippines. 418 p.

1979. IRRI Annual Report for 1978. Los Baños, Philippines. 478 p.

Lin, Y. H., C. N. Sun, and H. T. Feng. 1979. Resistance of Nilaparvata lugens to MIPC and MTMC in Taiwan. J. Econ. Entomol. 72:901-3.

Ling, K. C., E. R. Tiongco, and V. M. Aguiero. 1978. Rice ragged stunt, a new virus disease. Plant Dis. Repr. 62:701-5.

Lippold, P.C., J. O. Lee, Y. H. Kim, S. J. Park, J. Ryu, K. H. Chung, M. D. Davis, and K. Steenberg. 1978. Feeding of known planthopper on rice varieties labelled with \#32P. Intl. Rice Res. Newsl. 3(4):8-9.

Mani, M., and S. Jayaraj. 1976. Biological investigations on the resurgence of rice blue leafhopper, Zygina maculifrons (Motch.) Indian J. Expl. Biol. 14:636-7.

McClure, M. S. 1977. Resurgence of the scale Fiorinia externa (Homoptera: Diaspididae) on hemlock following insecticide application. Environ. Entomol. 6:480-484.

Nagata, T., and S. Moriya. 1974. Resistance in Brown planthopper Nilaparvata lugells (Stål) to lindane. (In Japanese with English abstract). Jap. J. Appl. Entomol. Zool. 18:73-80. 
Reynolds, H. T. 1971. A world review of the problem of insect population upsets and resurgences caused by pesticide chemicals. P. 108-12. In J. E. Swift (ed.), Agricultural Chemicals-Harmony or Discord for Food, People, Environment. Univ. of California Div. of Agric. Sciences.

Shepard, M., G. R. Carner, and S. G. Turnipseed. 1977. Colonization and resurgence of insect pests of soybean in response to insecticides and field isolation. Environ. Entomol. 6:501-6.

Sogawa, K., and M. D. Pathak. 1970. Mechanisms of brown planthopper resistance in Mudgo variety of rice (Hemiptera: Delphacidae). Appl. Ent. Zool. 5:145-58.

Suenaga, H. 1963. Analytical studies on the ecology of two species of planthoppers, the white back planthopper (Sogatella furcifera Horvath) and the brown planthopper (Nilaparvata lugens Stål), with special reference to their outbreaks [in Japanese]. Bull. Kyushu Agric. Exp. Stn. 8:1-152.

Vrie, van de M., J. A. McMurtry, and C. B. Huffaker. 1972. Ecology of tetranychid mites and their natural enemies: A review. III. Biology, ecology, and pest status and host plant reactions of tetranychids. Hilgardia 41:343-432. 